\title{
Hsp70 Inhibits Aminoglycoside-Induced Hair Cell Death and is Necessary for the Protective Effect of Heat Shock
}

\author{
Mona Taleb ${ }^{1}$, Carlene S. Brandon ${ }^{1}$, Fu-Shing Lee $^{2}$, Margaret I. Lomax ${ }^{3}$, Wolfgang H. Dillmann ${ }^{4}$, \\ AND Lisa L. Cunningham ${ }^{1}$ \\ ${ }^{1}$ Pathology and Laboratory Medicine, Medical University of South Carolina, Charleston, SC 29403, USA \\ ${ }^{2}$ Department of Otolaryngology—Head and Neck Surgery, Medical University of South Carolina, Charleston, SC 29425, USA \\ ${ }^{3}$ Kresge Hearing Research Institute and Department of Otolaryngology, University of Michigan, Ann Arbor, MI 48109, USA \\ ${ }^{4}$ Department of Endocrinology, School of Medicine, University of California, San Diego, La Jolla, CA 92093, USA
}

Received: 21 December 2007; Accepted: 17 April 2008; Online publication: 30 May 2008

\begin{abstract}
Sensory hair cells of the inner ear are sensitive to death from aging, noise trauma, and ototoxic drugs. Ototoxic drugs include the aminoglycoside antibiotics and the antineoplastic agent cisplatin. Exposure to aminoglycosides results in hair cell death that is mediated by specific apoptotic proteins, including cJun N-terminal kinase (JNK) and caspases. Induction of heat shock proteins (Hsps) is a highly conserved stress response that can inhibit JNK- and caspasedependent apoptosis in a variety of systems. We have previously shown that heat shock results in a robust upregulation of Hsps in the hair cells of the adult mouse utricle in vitro. In addition, heat shock results in significant inhibition of both cisplatin- and aminoglycoside-induced hair cell death. In our system, Hsp70 is the most strongly induced Hsp, which is upregulated over 250-fold at the level of mRNA $2 \mathrm{~h}$ after heat shock. Therefore, we have begun to examine the role of Hsp70 in mediating the protective effect of heat shock. To determine whether Hsp70 is necessary for the protective effect of heat shock against aminoglycoside-induced hair cell death, we utilized utricles from $H s p 70.1 / 3^{-1-}$ mice. While heat shock inhibited gentamicin-induced hair cell death in wild-type utricles, utricles from $H s p 70.1 / 3^{-1}$ mice were not protected. In addition, we have examined
\end{abstract}

Correspondence to: Lisa L. Cunningham · Pathology and Laboratory Medicine - Medical University of South Carolina - Charles, SC 29403, USA. Telephone: +1-843-7928324; fax: +1-843-7920368; email: cunninll@musc.edu the role of the major heat shock transcription factor, Hsfl, in mediating the protective effect of heat shock. Utricles from $\mathrm{Hsfl}^{-/-}$mice and wild-type littermates were exposed to heat shock followed by gentamicin. The protective effect of heat shock on aminoglycoside-induced hair cell death was only observed in wildtype mice and not in $\mathrm{Hsfl}^{-/-}$mice. To determine whether Hsp70 is sufficient to protect hair cells, we have utilized transgenic mice that constitutively overexpress Hsp70. Utricles from Hsp70-overexpressing mice and wild-type littermates were cultured in the presence of varying neomycin concentrations for $24 \mathrm{~h}$. The Hsp70-overexpressing utricles were significantly protected against neomycin-induced hair cell death at moderate to high doses of neomycin. This protective effect was achieved without a heat shock. Taken together, these data indicate that Hsp70 and Hsfl are each necessary for the protective effect of heat shock against aminoglycoside-induced death. Furthermore, overexpression of Hsp70 alone significantly inhibits aminoglycoside-induced hair cell death.

Keywords: ototoxicity, vestibular, utricle, Hsf1 knockout, Hsp70 knockout, Hsp70 overexpressor

\section{INTRODUCTION}

In humans, hearing is the most commonly impaired sensory modality (Adams et al. 1999). One common cause of hearing loss involves the death of hair cells 
in the inner ear, which can be triggered by a number of stressors including noise trauma, drug toxicity, aging, and certain genetic conditions. In the US, hearing loss represents the sixth most prevalent chronic health problem (Adams et al. 1999). The high prevalence of this condition is related to the fact that, in contrast to hair cells of nonmammalian vertebrates, mammalian hair cells are not regenerated after they die.

Aminoglycoside antibiotics are among the ototoxic drugs that induce hair cell death in the inner ear. In recent years, significant progress has been made in characterizing aminoglycoside-induced hair cell death. Several studies show both molecular and morphological evidence that ototoxic hair cell death is apoptotic (Lang and Liu 1997; Forge and Li 2000; Cunningham et al. 2002; Matsui et al. 2002, 2003; Cheng et al. 2003; Mangiardi et al. 2004; Eshraghi et al. 2007). Aminoglycosides lead to the activation of caspases, and broad-spectrum caspase inhibitors suppress aminoglycoside-induced hair cell death (Cunningham et al. 2002; Matsui et al. 2002, 2003; Cheng et al. 2003; Tabuchi et al. 2007). In addition, in both the auditory and vestibular systems, inhibition of the JNK signaling pathway has been shown to protect hair cells against aminoglycoside-induced death (Pirvola et al. 2000; Ylikoski et al. 2002; Matsui et al. 2004; Sugahara et al. 2006; Eshraghi et al. 2007).

Heat shock proteins (Hsps) are induced in response to a wide variety of cellular and environmental stresses, including extreme temperatures, extreme ion concentrations, cellular energy depletion, and exposure to toxic substances. This induction of Hsps is a highly conserved stress response that serves to protect cells against subsequent cellular stresses, thus promoting cellular survival (Martindale and Holbrook 2002). The protective effect of Hsp upregulation may be attributed to the function of Hsps as protein chaperones. Hsps assist in the synthesis, assembly, folding, translocation, and degradation of proteins by ensuring appropriate protein conformation (Hartl 1996). However, Hsps can also inhibit apoptosis in a variety of systems by interfering with apoptotic signaling cascades. Hsp70 has been shown to inhibit JNK activation and cytochrome $c$ release from the mitochondria (Mosser et al. 1997; Tsuchiya et al. 2003). In addition, Hsp70 and Hsp90 have both been shown to interfere with apoptosome formation required for caspase- 9 activation (Beere et al. 2000; Li et al. 2000; Pandey et al. 2000; Saleh et al. 2000). Remarkably, Hsp70 has been shown to inhibit cell death even after downstream mediators, including caspase-3, have been activated (Jaattela et al. 1998).

We have previously demonstrated that heat shock, which strongly induces Hsp70 in the adult mouse utricle preparation, inhibits aminoglycoside-induced hair cell death (Cunningham and Brandon 2006). As mentioned above, there is evidence from other systems that Hsp70 can inhibit some of the same pathways that mediate aminoglycoside-induced hair cell death, including caspases and JNK. Therefore, we have examined the role of Hsp70 in the inhibition of aminoglycoside-induced hair cell death. Here, we have asked whether Hsp70 is necessary for the protective effect of heat shock against aminoglycoside-induced hair cell death and whether overexpression of Hsp70 is sufficient to protect hair cells against aminoglycoside-induced death. To address these questions, we utilized two lines of genetically modified mice, Hsp $70.1 / 3^{--}$mice and Hsp70-overexpressing mice, respectively (Marber et al. 1995; Hunt et al. 2004).

\section{METHODS}

\section{Animals}

All mice were euthanized with an overdose of Nembutal (Abott Laboratories, USA) and decapitated. All animal protocols were approved by the MUSC Institutional Animal Care and Use Committee. All mice were maintained in the central animal care facility at the Medical University of South Carolina (Charleston, SC, USA).

\section{CBA/J mice}

Adult CBA/J mice (4 to 6 weeks old) were obtained from Harlan (Indianapolis, IN, USA).

Hsp $70.1 / 3^{--}$mice

Hsp $70.1 / 3^{-1}$ mice were obtained from the Mutant Mouse Regional Resource Center at the University of California at Davis. In $H s p 70.1 / 3^{-/-}$mice, both $H s p 70.1$ and $H s p 70.3$ genes have been inactivated by replacement of approximately $11 \mathrm{~kb}$ of genomic DNA on chromosome 17 with a $N E O$ gene, which is under the control of an RNA polymerase II gene promoter

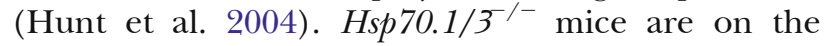
mixed genetic background B6;129S. Because Hsp70.1/ $3^{-1-}$ mice are viable and fertile, litters were obtained by matings between knockout animals. B6129SF2/J mice were obtained from the Jackson Laboratory (Bar Harbor, ME, USA) and used as controls.

\section{Hsp70-overexpressing mice}

Hsp70-overexpressing mice constitutively express rat Hsp70 under the control of the human cytomegalovirus immediate early enhancer (hCMV-IE) and chicken $\beta$-actin promoter (Marber et al. 1995). These 
transgenic mice are on a $\mathrm{BALB} / \mathrm{c} \times \mathrm{C} 57 \mathrm{BL} / 6$ background. Male Hsp70-overexpressing mice were mated with wild-type female CB6F1 mice, which were obtained from the Jackson Laboratory. Resulting litters were approximately $50 \%$ wild-type (transgene negative; homozygous) and 50\% Hsp70-overexpressing mice (transgene positive; heterozygous).

$\mathrm{Hsf1}^{-/-}$mice

In $\mathrm{Hsfl}^{-1-}$ mice, a 1.8-kb genomic fragment has been replaced with a 2-kb NEO insert using a gene targeting vector for $\mathrm{Hsf1}$ (McMillan et al. 1998). $\mathrm{HsfT}^{-1}$ mice, originally on the mixed genetic background C,129X1 (129X1/SvJ × BALB/c; McMillan et al. 1998), were crossed to $\mathrm{CBA} / \mathrm{CaJ}$. $\mathrm{F} 1$ progeny were tested for the A/G polymorphism in exon 7 of the $C d h 23$ gene. F1 mice containing the $C d h 23$ gene from $\mathrm{CBA} / \mathrm{CaJ}$ were backcrossed to CBA/CaJ (The Jackson Laboratory) for at least four generations. Male heterozygous mice $\left(\mathrm{Hsfl}^{+-}\right)$were mated with female heterozygous $\left(H s \mathrm{fl}^{+-}\right)$mice. In a total of 256 pups, there were 75 wild-types $\left(\mathrm{Hsfl}_{\mathrm{f}}^{++}\right), 149$ heterozygotes $\left(\mathrm{Hsfl}^{+-}\right)$, and 32 Hsfl-deficient $\left(\mathrm{Hsf1}^{-1-}\right)$ mice. This corresponds to a 1:2:0.43 ratio, respectively, indicating that some prenatal lethality is observed in $\mathrm{Hsfl}^{-/-}$mice on the CBA background. This is similar to reports on $\mathrm{Hsfl}^{-/-}$mice on the C,129-Hsf1 and R,129-Hsf1 backgrounds (Xiao et al. 1999).

\section{Genotyping}

Twenty-one days after birth, pups of transgenic and knockout strains were weaned and genotyped. Tail clips $(1 \mathrm{~mm})$ were lysed using DirectPCR Lysis Reagent (Tail; Viagen Biotech no. 101-T, Los Angeles, CA, USA). Crude DNA obtained from tail lysates was used in one-step polymerase chain reaction (PCR) genotyping (TaqMan Core Reagent Kit, Applied Biosystems no. N808-0228, Foster City, CA, USA; Mastercycler, Eppendorf no. 5333, Hamburg, Germany). The following primers were used:

Hsp $70.1 / 3^{-1-}$ mice

Forward primer 5'-GAACGGAGGATAAAGTTAGG-3',

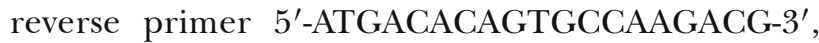
yielding a 780-bp product of the inserted $N E O$ gene.

\section{B6129SF2/J mice}

Forward primer 5'-GTACACTTTAAACTCCCTCC-3', reverse primer 5'-CTGCTTCTCTTGTCTTCG-3', yielding a 454-bp product of the $H s p 70$ gene.

\section{Hsp70-overexpressing mice}

Forward primer 5'-ATTACGGGGTCATTAGTTCATAGCC-3', reverse primer 5'-GTAGGAAAGTCCCA-
TAAGGTCATGT-3', yielding a 280-bp product of the CMV-IE region of the rat $H s p 70$ transgene.

Hsf1 ${ }^{-/}$mice

Forward Hsf1 primer 5'-AGACCTGTCCTGTGTGCC TAGC-3', reverse Hsf1 primer 5'-CAGTTCAACTGCC TACACAGACC-3', yielding a 562-bp product of the Hsf1 gene; forward NEO primer 5'-AAGTATCCAT CATGGCTGATGC-3', reverse $N E O$ primer $5^{\prime}$-TAGG CAACGCTATGTCCTGATA-3' , yielding a 339-bp product of the inserted $N E O$ gene.

\section{Mouse utricle organ culture}

Adult mouse utricle dissections and culture conditions have previously been described in detail (Cunningham 2006). Briefly, adult mouse utricle dissections were performed under sterile conditions. Whole utricles with otoconia and stroma intact were cultured freefloating in a 24-well tissue culture plate (one to eight utricles per well). Each well contained $1 \mathrm{ml}$ of culture medium, consisting of 2:1 $(v / v)$ basal medium Eagle (Sigma, St. Louis, MO, USA) and Earle's balanced salt solution (Invitrogen, Carlsbad, CA, USA), as well as $5 \%$ fetal bovine serum (FBS; Invitrogen), and $50 \mathrm{U} / \mathrm{ml}$ penicillin $\mathrm{G}$ (Sigma). Neomycin sulfate solution (Sigma) was supplied as a $10-\mathrm{mg} / \mathrm{ml}$ stock solution. Using culture medium, neomycin sulfate solutions were prepared at final concentrations ranging from 1 to $4 \mathrm{mM}$. Note: The dose-response curve in Figure 3 contains one data point (1 $\mathrm{mM}$ ) that was previously published (Cunningham and Brandon 2006). Control utricles were cultured in the absence of neomycin. Gentamicin (Sigma) was supplied as a $51-\mathrm{mg} / \mathrm{ml}$ stock solution. Gentamicin solutions at final concentrations ranging from 2.5 to $25 \mathrm{mM}$ were prepared using culture medium. Control utricles were cultured in culture medium only. Utricle cultures were maintained in an incubator at $37^{\circ} \mathrm{C}$ in a $5 \% \mathrm{CO}_{2} / 95 \%$ air environment.

\section{Heat shock protocol}

The heat shock protocol has previously been described (Cunningham and Brandon 2006). Briefly, utricles were cultured overnight at $37^{\circ} \mathrm{C}$ before heat shock. For experiments involving heat shock, freefloating utricles and surrounding culture media were transferred from the 24-well tissue culture plate into sterile 1.5-ml microcentrifuge tubes. Tubes containing utricles to be heat shocked were placed into a water bath at $43^{\circ} \mathrm{C}$ for $30 \mathrm{~min}$. Control utricles (no heat shock) were replaced in the incubator at $37^{\circ} \mathrm{C}$. After the heat shock, all utricles were returned to the appropriate wells of the tissue culture plate and maintained in culture at $37^{\circ} \mathrm{C}$ for $6-30 \mathrm{~h}$. 


\section{Immunohistochemistry}

\section{Whole-mount utricles}

To allow for differential hair cell counts in the extrastriolar and striolar regions, utricles were processed for whole-mount, double-label fluorescent immunohistochemistry as previously described (Cunningham and Brandon 2006). Utricles were fixed in $4 \%$ paraformaldehyde overnight at $4^{\circ} \mathrm{C}$. They were washed with phosphate-buffered saline (PBS) before otoconia removal. Otoconia were removed using either two pairs of no. 55 forceps (Fine Science Tools no. 11255-20, Foster City, CA, USA) or by a stream of phosphate-buffered saline using a syringe. For $3 \mathrm{~h}$ at room temperature, utricles were incubated in blocking solution ( $2 \%$ bovine serum albumin $/ 0.8 \%$ normal goat serum $/ 0.4 \%$ Triton$\mathrm{X}$ in PBS). The following primary antibodies were diluted in blocking solution: monoclonal anti-calmodulin (Sigma no. C 3545; 1:150) and polyclonal anticalbindin (Chemicon no. AB1778, Temecula, CA, USA; $1: 200)$. Utricles were incubated in primary antibody solution at $4^{\circ} \mathrm{C}$ overnight, then washed with blocking solution. The following secondary antibodies were diluted in blocking solution: Alexa 488 conjugated goat anti-mouse IgG (Invitrogen no. A11001; 1:500) and Alexa 594 conjugated goat anti-rabbit IgG (Invitrogen no. A11012; 1:500). Utricles were incubated in secondary antibody solution for $4 \mathrm{~h}$ in the dark at room temperature on a rocking platform. They were washed and mounted on slides using Fluoromount-G (Southern Biotech, Birmingham, AL, USA). Utricles were visualized using a Zeiss Axioplan 2 fluorescent microscope and a high-resolution monochrome digital camera (Zeiss Axiocam MR). Using imaging software (Zeiss AxioVision), four striolar (calmodulin- and calbindinpositive) and four extrastriolar (calmodulin-positive, calbindin-negative), $900 \mu \mathrm{m}^{2}(30 \mu \mathrm{m} \times 30 \mu \mathrm{m})$ areas were selected, and hair cells were counted in each square. Hair cells counts from the four extrastriolar and four striolar regions are averaged separately and reported as the striolar or extrastriolar hair cell density for each utricle.

\section{Sectioned utricles}

Utricles to be sectioned were prepared according to Desai et al. (2005). Utricles were fixed with $4 \%$ paraformaldehyde with $1 \%$ picric acid (Sigma no. P6744), and 5\% sucrose (Fisher no. S5-500, Pittsburgh, $\mathrm{PA}, \mathrm{USA})$ in $0.1 \mathrm{M}$ Sorenson's phosphate buffer (40 mM Na $\mathrm{HPO}_{4} / 95 \mathrm{mM} \mathrm{NaH} \mathrm{PO}_{4} ; \mathrm{pH}$ 7.4) (1× $\mathrm{PB})$ for $1 \mathrm{~h}$ at room temperature. The fixative was removed, and utricles were placed in a $30 \%$ sucrose solution (in $\mathrm{ddH}_{2} \mathrm{O}$ ). The tissue was microwaved in a water-chilled Pelco BioWave DFR-10 (Ted Pella, Inc., Redding, CA, USA) at $150 \mathrm{~W}$ for $2 \mathrm{~min}$ while maintaining a temperature below $21^{\circ} \mathrm{C}$. Utricles were agitated overnight at $4^{\circ} \mathrm{C}$ in a $30 \%$ sucrose solution. They were treated with Cal-Ex (Fisher CS510-1D) for $30 \mathrm{~s}$ at room temperature to dissolve otoconia. Utricles were washed with $1 \times \mathrm{PB}$, then treated with a $1 \%$ sodium borohydride solution (Sigma no. S9125). Utricles were washed again and embedded in a solution consisting of $14 \%$ Difco $^{\mathrm{TM}}$ Gelatin (BD no. 214340, Sparks, MD, USA) and 30\% sucrose. Frozen sections were cut at $35 \mu \mathrm{m}$ thickness and placed in $1 \times$ PB. Sections were treated with $4 \%$ Triton $\mathrm{X}-100$ in $1 \times$ PB (Sigma no. T-8787) for $1 \mathrm{~h}$ followed by blocking $1 \mathrm{~h}$ in $0.01 \mathrm{M}$ PBS $(1 \times \mathrm{PBS})$ with $0.5 \%$ fish gelatin (Sigma no. G7765), 1\% BSA (Sigma no. A3294), and $0.5 \%$ Triton X-100. Primary antibodies were added: antiHsp70 (Stressgen no. SPA-810, Victoria, BC, Canada; 1:200), and anti-myosin VIIa (Proteus BioSciences Inc., Ramona, CA, USA). Sections were incubated with agitation overnight at $4^{\circ} \mathrm{C}$. Sections were washed, then incubated for $2 \mathrm{~h}$ in Alexa 488 conjugated goat anti-mouse IgG (Invitrogen no. A11001; 1:500 in fish block) and Alexa 594-conjugated goat anti-rabbit IgG (Invitrogen no. A11012; 1:500 in fish block). After washing, Hoechst stain (1 $\mu \mathrm{g} / \mathrm{ml}$ in $1 \times$ PBS) was applied for $30 \mathrm{~s}$. The sections were washed with $1 \times$ PBS and mounted on glass slides using Fluoromount $G$ (Southern Biotech). Sections were visualized using a Zeiss Axioplan 2 fluorescent microscope and a high-resolution monochrome digital camera (Zeiss Axiocam MR).

\section{Western blot analysis}

Utricles (12 per condition) were homogenized in cell lysis buffer (Epitomics no. 3500-1, Burlingame, CA, USA) supplemented with $1 \mathrm{mM}$ phenylmethanesulphonylfluoride. Protein lysates were subjected to sodium dodecyl sulfate polyacrylamide gel electrophoresis (SDS-PAGE) using 4-15\% Tris-HCl gels (Bio-Rad, Hercules, CA, USA), then transferred onto polyvinylidene fluoride (PVDF) membranes (Invitrogen). All primary antibodies were diluted in blocking solution, consisting of $0.2 \%$ I-Block (Tropix, Bedford, MA, USA), 0.1\% TWEEN 20 (Sigma) in tris-buffered saline. Primary antibodies included anti-Hsp90 (Cell Signaling Technology no. 4874, Danvers, MA, USA; 1:1,000), anti-Hsp70 (Stressgen no. SPA-810; 1:1,000), anti-Hsp27 (Upstate no. 06-517, Lake Placid, NY, USA; 1:1,000), and anti-actin (Sigma no. A 2066; 1:1,000). Signal amplification and visualization were achieved using SuperSignal West Dura Extended Duration Substrate (Pierce Biotechnology no. 34075, Rockford, IL, USA). When probing the membrane for actin, ECL Plus Western Blotting Detection Reagents (GE Healthcare no. RPN2132, Piscataway, NJ, USA) were used for visualization. 


\section{Statistical analyses}

Data were analyzed with either a one-way, two-way, or three-way analysis of variance (ANOVA) using statistical software SYSTAT 8.0 (San Jose, CA, USA). Post hoc tests were performed using pooled variances.

\section{RESULTS}

Heat shock induces Hsp70 in both hair cells and support cells

We have previously shown by real-time PCR and immunohistochemistry in whole-mount utricles that Hsp70 is upregulated in hair cells in response to heat shock (Cunningham and Brandon 2006). To determine whether heat shock also induces Hsp70 in support cells, control (Fig. 1A, C, E, and G) and heat shocked utricles (Fig. 1B, D, F, and H) were sectioned and labeled for Hsp70 (Fig. 1E and F) and myosin VIIa (Fig. 1A and B). Nuclei were labeled with Hoechst stain (Fig. 1C and D). Compared to control utricles (Fig. 1G), heat shocked utricles (Fig. 1H) demonstrate stronger immunoreactivity for Hsp70 in both hair cells and support cells.
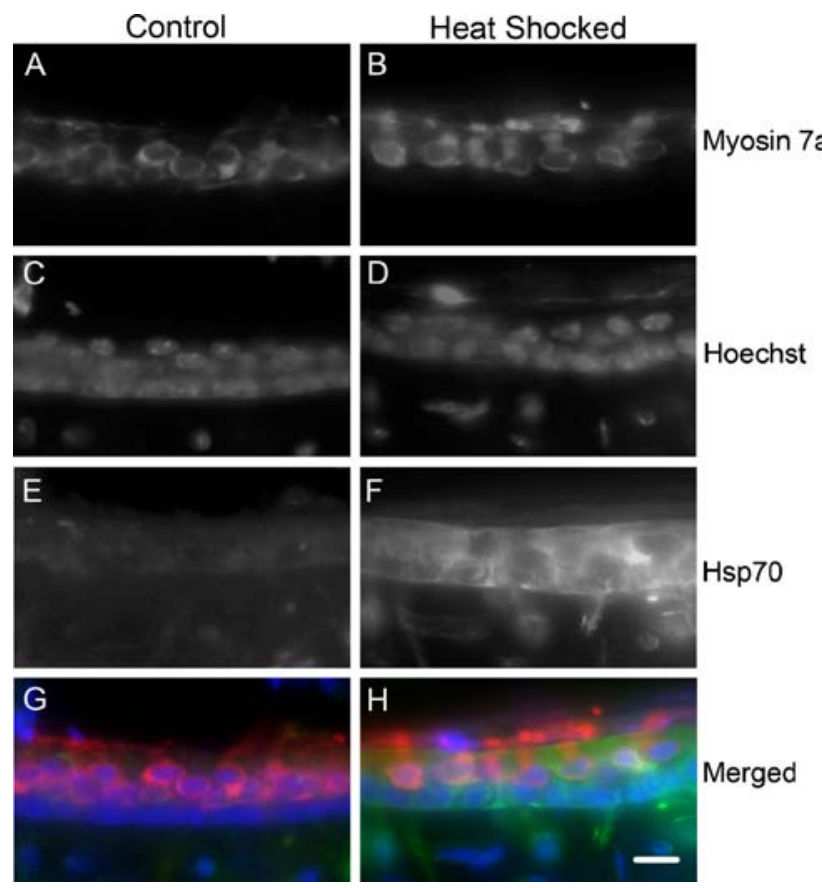

FIG. 1. Heat shock results in the induction of Hsp70 in both hair cells and support cells. Control (A, C, E, G) and heat shocked utricles $(\mathbf{B}, \mathbf{D}, \mathbf{F}, \mathbf{H})$ were labeled using anti-myosin VIla (red; A, B), Hoechst stain (blue; C, D), and anti-Hsp70 (green; E, F). Control utricles show little to no Hsp70 immunoreactivity (E, G). Hsp70 immunoreactivity is significantly increased in both the hair cell and support cell layers $6 \mathrm{~h}$ after heat shock (F, H). Scale bar represents $10 \mu \mathrm{m}$ and applies to all panels.
Protein levels of Hsp90, Hsp70, and Hsp27

Heat shock-induced Hsp expression was examined by Western blot. Relative protein levels of Hsp90, Hsp70, and Hsp27 were examined under the following conditions: (1) Utricles from CBA mice without heat shock; (2) Utricles from CBA mice with heat shock; (3) Utricles from wild-type littermates of Hsp70overexpressing mice without heat shock; (4) Utricles from wild-type littermates of Hsp70-overexpressing mice with heat shock; (5) Utricles from Hsp70-overexpressing mice without heat shock. As shown in Figure 2, heat shock resulted in a robust increase in Hsp70 in both CBA utricles and those from the wildtype littermates of the Hsp70-overexpressing mice. In addition, Hsp70 levels were higher in utricles from Hsp70-overexpressing mice compared to those from their wild-type littermates without heat shock (Fig. 2). The levels of Hsp70, however, were significantly higher in heat shocked utricles than in Hsp70overexpressing utricles (Fig. 2).

Compared to controls, Hsp90 did not change significantly with heat shock in either utricles from CBA mice or those from the wild-type littermates of the Hsp70-overexpressing colony (Fig. 2). While Hsp90 mRNA levels were similar in utricles of Hsp70-overexpressing and wild-type utricles (data not shown), Hsp90 protein levels were lower in utricles of Hsp70-overexpressing mice than in those of their wild-type littermates (Fig. 2). Hsp27 expression was induced in response to heat shock in CBA and wild-type utricles compared to controls. In addition, Hsp27 levels were slightly increased in Hsp70-overexpressing utricles compared to those from wild-type littermates both at the mRNA level (data not shown) and at the protein level (Fig. 2).

Heat shock inhibits neomycin-induced hair cell death across the neomycin dose-response curve

Using utricles from CBA mice, we have previously demonstrated that heat shock inhibits hair cell death induced by $1 \mathrm{mM}$ neomycin treatment (Cunningham and Brandon 2006). To determine if heat shock can inhibit neomycin-induced hair cell death across the neomycin dose-response curve, we extended these studies to include a broader range of neomycin concentrations. Control (no heat shock) and heat shocked utricles from CBA mice were cultured for $24 \mathrm{~h}$ at the following concentrations: $0,2,3$, and $4 \mathrm{mM}$ neomycin. In the absence of neomycin, control and heat shocked utricles have similar hair cell densities $\left(F_{1,87}=0.65, p>\right.$ 0.05; Fig. 3). At concentrations ranging from 1 to $4 \mathrm{mM}$ neomycin, hair cell counts in heat shocked utricles are significantly higher compared to control utricles (1 mM: $F_{1,97}=7.68, p<0.01 ; 2 \mathrm{mM}: F_{1,97}=35.62, p<$ 


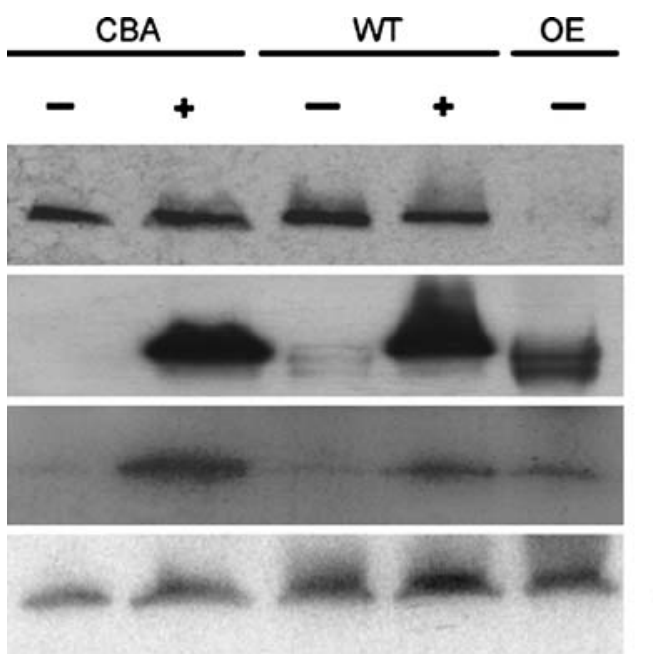

Heat shock

Hsp90

Hsp70

Hsp27

actin

FIG. 2. Protein levels of Hsp90, Hsp70, and Hsp27. Control and/or heat shocked utricles from CBA mice, $\mathrm{H}_{s p} 70$-overexpressing mice, and wild-type littermates were collected $6 \mathrm{~h}$ after heat shock. Protein lysates were subjected to SDS-PAGE and then transferred onto a PVDF membrane. Western blot analysis was performed using antibodies against Hsp90, Hsp70, Hsp27, and actin.

0.0001; $3 \mathrm{mM}: F_{1,97}=20.11, p<0.0001 ; 4 \mathrm{mM}: F_{1,87}=5.94$, $p<0.05$; Fig. 3). These data indicate that heat shock inhibits neomycin-induced hair cell death across the neomycin dose-response curve.

\section{Gentamicin kills utricular hair cells}

in a dose-dependent manner

The dose-response curve for neomycin in the mouse utricle preparation has been published previously (Cunningham et al. 2002). However, neomycin is not suitable for experiments utilizing utricles from $H s p 70^{-1-}$ mice and $\mathrm{Hsf1}^{-/-}$mice because each strain of knockout mice was generated by inserting a neomycin resistance gene into the locus of the target gene (see "Methods" section) (McMillan et al. 1998; Hunt et al. 2004). The neomycin resistance gene encodes an aminoglycoside phosphotransferase (APH $\left(3^{\prime}\right)$ ), which modifies the $3^{\prime}$-hydroxyl group of neomycin, kanamycin, and other aminoglycosides containing this functional group. Neither gentamicin nor streptomycin is a substrate for the $\mathrm{APH}\left(3^{\prime}\right)$ enzyme because they both lack this $3^{\prime}$-hydroxyl group (Wright and Thompson 1999). Gentamicin was selected for experiments involving utricles from $\mathrm{Hsp}_{\mathrm{f}} 70^{-/-}$and $H s f 1^{-/-}$mice because it is clinically more commonly used than streptomycin. In preliminary experiments designed to generate a dose-response curve for gentamicin, utricles from CBA mice were dissected under sterile conditions and cultured overnight. Utricles were cultured for $24 \mathrm{~h}$ in the presence of gentamicin at the following concentrations: 2.5, 5, 7.5, 10, 15, 20, $25 \mathrm{mM}$ gentamicin. Control utricles were

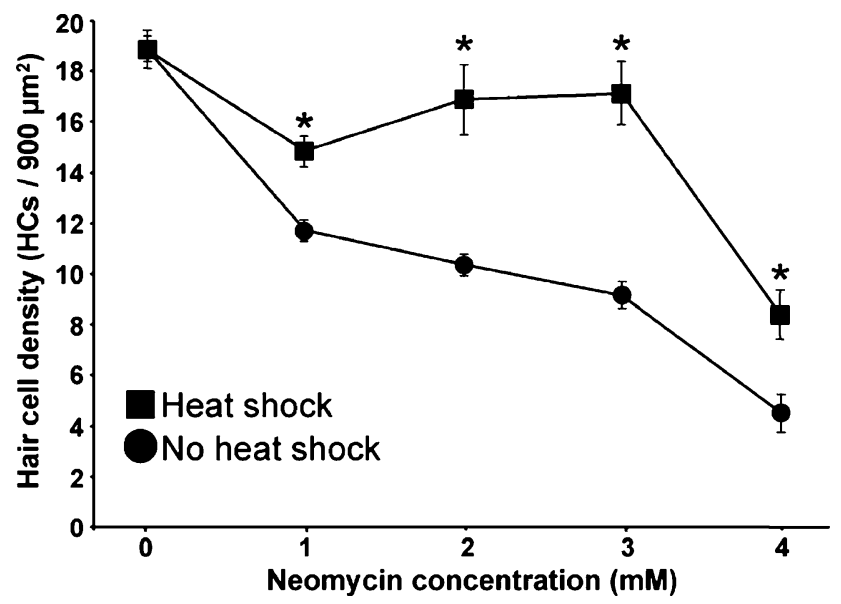

FIG. 3. Heat shock inhibits neomycin-induced hair cell death across the neomycin dose-response curve. To determine if heat shock can inhibit neomycin-induced hair cell death at a range of neomycin doses, control (no heat shock) and heat shocked utricles from CBA mice were cultured for $24 \mathrm{~h}$ at the following concentrations: $0,2,3$, and $4 \mathrm{mM}$ neomycin. Heat shock significantly inhibited neomycin-induced hair cell death at all neomycin concentrations. Note: The data point at $1 \mathrm{mM}$ neomycin had previously been published (Cunningham and Brandon 2006). Asterisks $\left({ }^{*}\right)$ indicate a significant difference in hair cell density in the extrastriolar region relative to that of utricles treated with neomycin alone. Data points represent mean \pm SEM for $n=4-31$ utricles per condition.

cultured in the absence of gentamicin. Extrastriolar and striolar hair cells were counted (Fig. 4). Gentamicin resulted in a dose-dependent loss of hair cells in both striolar $\left(F_{7,47}=12.36, p<0.0001\right)$ and extrastriolar regions $\left(F_{7,47}=34.13, p<0.0001\right)$. For subsequent experiments using utricles from $\mathrm{Hsp}_{\mathrm{p}} \mathrm{O}^{-/}$and $\mathrm{Hsfl}^{-1-}$ mice, a dose of $5 \mathrm{mM}$ gentamicin was used which is approximately in the middle of the dose-response

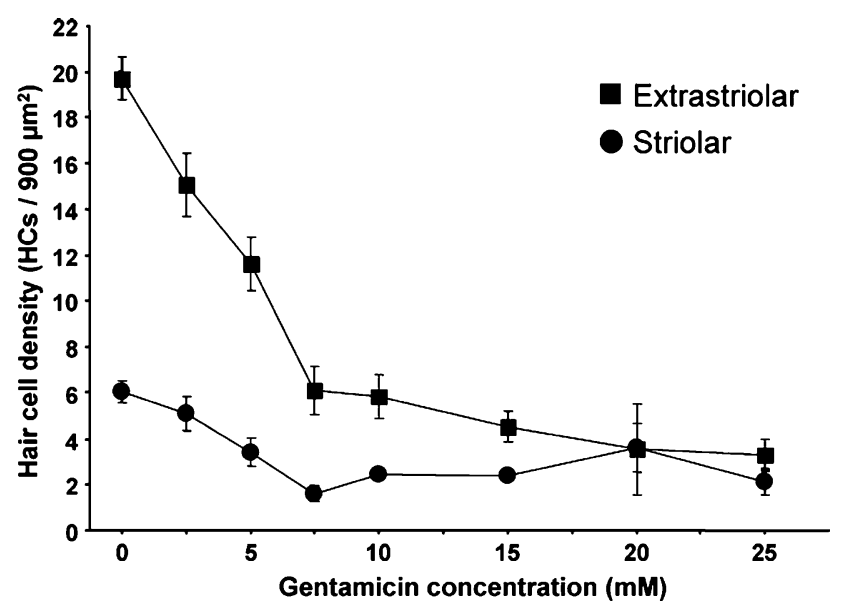

FIG. 4. Gentamicin kills utricular hair cells in a dose-dependent manner. To generate a dose-response curve for gentamicin, utricles from CBA mice were cultured at varying gentamicin concentrations at $37^{\circ} \mathrm{C}$ for $24 \mathrm{~h}$. Control utricles were cultured in the absence of gentamicin. Gentamicin treatment killed striolar and extrastriolar hair cells in a dose-dependent manner. Data points represent mean \pm SEM for $n=4-11$ utricles per condition. 
curve (Fig. 4). This dose of gentamicin is similar to other previously published vestibulotoxic gentamicin concentrations used in mammalian vestibular preparations in vitro (Forge and $\mathrm{Li}$ 2000; Takumida and Anniko 2005; Taura et al. 2006).

Hsf1 is necessary for the protective effect of heat shock against aminoglycoside-induced hair cell death

Hsps are transcriptionally activated in response to heat stress by members of the heat shock factor (Hsf) family of transcription factors, of which Hsfl is the primary mediator of the heat shock response (for review, Anckar and Sistonen 2007). To determine whether Hsfl is necessary for the protective effect of heat shock against aminoglycoside-induced hair cell death, we utilized $\mathrm{Hsfl}^{-/-}$mice (McMillan et al. 1998). Utricles from both $\mathrm{Hsfl}^{-/-}$mice and wild-type littermates were cultured under the following conditions: (1) no heat shock, without gentamicin treatment; (2) heat shock, without gentamicin treatment; (3) no heat shock, with gentamicin treatment $(5 \mathrm{mM}$ for $24 \mathrm{~h})$; (4) heat shock, with gentamicin treatment $(5 \mathrm{mM}$ for $24 \mathrm{~h})$. Figure 5 shows extrastriolar hair cell counts for wild-type and $\mathrm{Hsfl}^{-/-}$mouse utricles of all four experimental conditions. While heat shock inhibits gentamicin-induced hair cell death in wildtype utricles $\left(F_{1,36}=10.01, p<0.01\right)$, this protective effect of heat shock is not observed in $\mathrm{Hsfl}^{-/-}$mouse utricles $\left(F_{1,36}=1.74, p>0.05\right)$. These data indicate that Hsfl is necessary for the protective effect of heat shock against aminoglycoside-induced hair cell death.

Hsp70 is necessary for the protective effect of heat shock against aminoglycoside-induced hair cell death

Heat shock induces a number of stress-related genes, including several Hsps. In our system, Hsp70 is the most strongly-induced Hsp in response to heat shock (Cunningham and Brandon 2006) (Fig. 2). To determine whether Hsp70 is necessary for the protective effect of heat shock against aminoglycosideinduced hair cell death, we utilized utricles from Hsp $70.1 / 3^{-1}$ double knockout mice (Hunt et al. 2004). Utricles from $H s p 70.1 / 3^{-1-}$ and wild-type mice were exposed to the same conditions as in experiments involving the $\mathrm{Hsfl}^{-/-}$mice described above. Relative to controls, heat shock alone does not alter hair cell densities in either genotype (Fig. 6). Exposure to gentamicin results in significant hair cell loss in both $H s p 70.1 / 3^{-/-}$and wild-type mice. The protective effect of heat shock against aminoglycosideinduced hair cell death is seen in wild-type mice $\left(F_{1,64}=11.03, p<0.01\right)$, but not in $H s p 70.1 / 3^{-/-}$mice

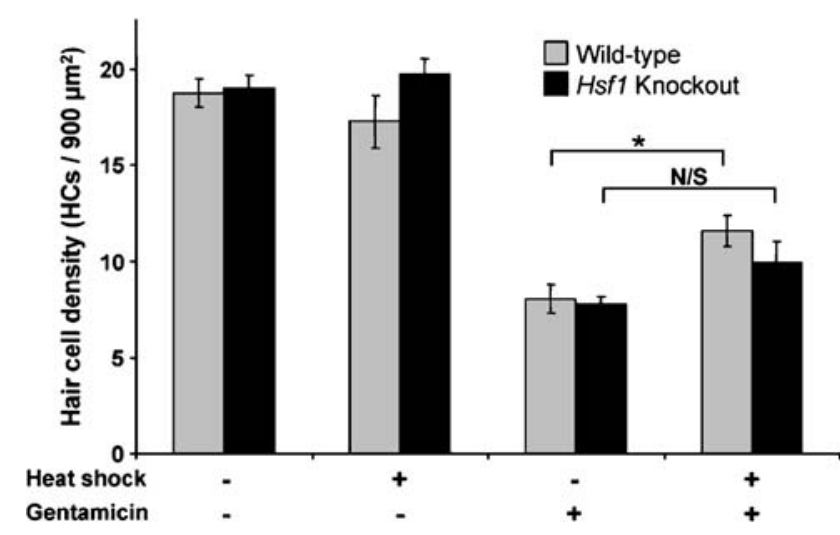

FIG. 5. Hsf1 is necessary for the protective effect of heat shock on aminoglycoside-induced hair cell death. Utricles from both wild-type and $\mathrm{Hsfl}^{--}$mice were cultured, heat shocked, and/or exposed to gentamicin. Gentamicin results in similar degrees of hair cell loss in both wild-type and $\mathrm{Hsfl}^{-/}$mouse utricles. Heat shock significantly inhibits gentamicin-induced hair cell death in wild-type utricles, but not in $\mathrm{Hsf1}^{-1-}$ mouse utricles. Asterisks $\left(^{*}\right)$ indicate a significant difference in hair cell density in the extrastriolar region. N/S Not significant. Bars represent mean \pm SEM for $n=3-15$ utricles per condition.

$\left(F_{1,64}=0.01, p>0.05\right)$. These data indicate that Hsp70 is necessary for the protective effect of heat shock against aminoglycoside-induced hair cell death.

\section{Hsp70 overexpression inhibits neomycin-induced hair cell death}

To determine whether Hsp70 is sufficient to protect against neomycin-induced hair cell death, utricles from Hsp70-overexpressing mice and wild-type littermates were exposed to $2 \mathrm{mM}$ neomycin for $24 \mathrm{~h}$. Four groups of utricles were cultured: (1) Wild-type utricles without neomycin treatment; (2) Wild-type utricles treated with $2 \mathrm{mM}$ neomycin $(24 \mathrm{~h})$; (3) Hsp70overexpressing utricles without neomycin treatment; (4) Hsp70-overexpressing utricles treated with $2 \mathrm{mM}$ neomycin $(24 \mathrm{~h})$. At the end of the culture period, utricles from all groups were fixed and prepared for double-label fluorescent immunohistochemistry using antibodies against calmodulin and calbindin. Hair cells were counted in striolar and extrastriolar regions. Untreated utricles from Hsp70-overexpressing and wild-type mice have comparable hair cell densities (Fig. 7A, C, and E). Neomycin exposure resulted in significant hair cell death in both extrastriolar $\left(F_{1,38}=44.21, p<0.0001\right)$ and striolar regions $\left(F_{1,35}=25.49, p<0.0001\right)$ of wild-type utricles (Fig. 7B and $\mathrm{E})$. In contrast to wild-type utricles, hair cells in both the extrastriolar $\left(F_{1,38}=12.51, p<0.01\right)$ and striolar regions $\left(F_{1,35}=4.21, \mathrm{p}<0.05\right)$ of Hsp70overexpressing utricles were significantly protected against neomycin-induced hair cell death (Fig. 7D and E). These data indicate that Hsp70 overexpression inhibits neomycin-induced hair cell death. 


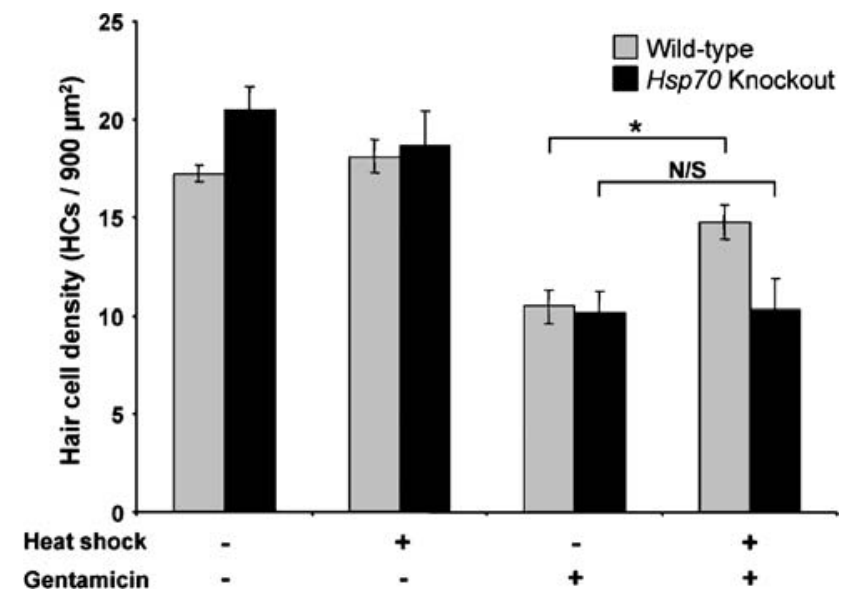

FIG. 6. Hsp70 is necessary for the protective effect of heat shock against aminoglycoside-induced hair cell death. Utricles from both wildtype and Hsp70.1/3-/- mice were cultured, heat shocked, and/or exposed to gentamicin. Gentamicin kills hair cells from both wild-type and $H s p 70.1 / 3^{-1-}$ mouse utricles. Heat shock significantly inhibits gentamicin-induced hair cell death in wild-type utricles, but not in Hsp $70.1 / 3^{-1-}$ mouse utricles. Asterisks (*) indicate a significant difference in hair cell density in the extrastriolar region. $N / S$ Not significant. Bars represent mean \pm SEM for $n=8-11$ utricles per condition.

\section{Hsp70 overexpression can account for much} of the protective effect of heat shock

We examined whether Hsp70 overexpression alone can account for the protective effect seen in heatshocked utricles. Utricles were cultured under the following conditions: (1) wild-type utricles, no heat shock, without neomycin treatment; (2) wild-type utricles with neomycin treatment; (3) wild-type utricles, heat shocked, with neomycin treatment (2 mM for $24 \mathrm{~h}$ ); (4) Hsp70-overexpressing utricles (without heat shock) with neomycin treatment (2 mM for $24 \mathrm{~h}$ ). As indicated in Figure 8, neomycin treatment causes significant hair cell death in wildtype utricles. Hsp70-overexpressing utricles $\left(F_{1,36}=\right.$ 7.84, $p<0.01)$ and heat-shocked wild-type utricles $\left(F_{1,36}=15.14, p<0.001\right)$ are both significantly protected against neomycin-induced hair cell death. Hair cell counts from heat shocked wild-type utricles and Hsp70-overexpressing utricles (without heat shock), both cultured in the presence of neomycin, are not statistically different $\left(F_{1,36}=0.67, p>0.05\right)$. These data suggest that the overexpression of Hsp70 can account for much of the protective effect of heat shock at a moderate dose of neomycin.

Hsp70 overexpression inhibits hair cell death at moderate to high doses of neomycin

To examine the potential protective effect of Hsp70 overexpression on hair cell death induced by various doses of neomycin, we generated a neomycin doseresponse curve in utricles from Hsp70-overexpressing and wild-type mice. Utricles from both Hsp70- overexpressing mice and their wild-type littermates were cultured in the presence of the following neomycin concentrations for $24 \mathrm{~h}$ : 1, 2, 3, and $4 \mathrm{mM}$ neomycin. Control utricles were cultured in the absence of neomycin. Utricles were fixed and processed for double-label fluorescent immunohistochemistry to allow for hair cell counts. In the absence of neomycin $\left(F_{1,70}=0.64, \mathrm{p}>0.05\right)$ and at $1 \mathrm{mM}$ neomycin $\left(F_{1,70}=\right.$ $0.35, \mathrm{p}>0.05)$, hair cell densities of wild-type and Hsp70-overexpressing utricles were similar (Fig. 9). Compared to wild-type utricles, Hsp70-overexpressing
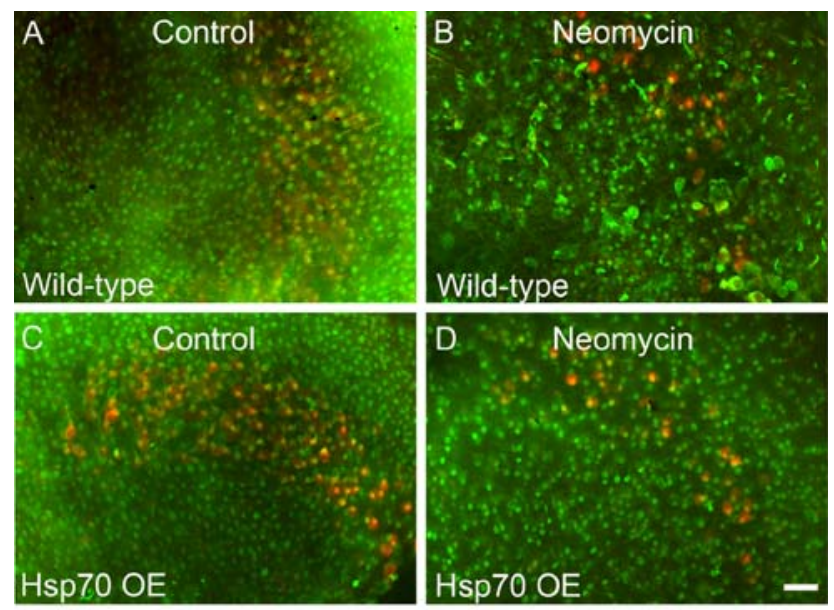

E

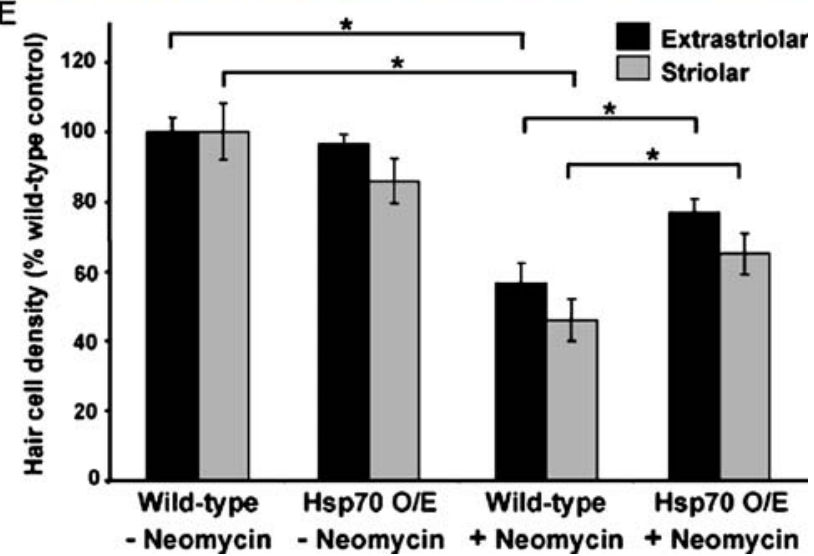

FIG. 7. Hsp70 overexpression inhibits neomycin-induced hair cell death. Utricles from wild-type (A, B) and Hsp70-overexpressing mice $(\mathbf{C}, \mathbf{D})$ were cultured under control conditions $(\mathbf{A}, \mathbf{C})$ or exposed to $2 \mathrm{mM}$ neomycin (B, D) for $24 \mathrm{~h}$. The utricles were then fixed and double-labeled with calmodulin and calbindin. Utricles from wildtype mice showed significant loss of hair cells in both the striolar and extrastriolar regions when exposed to neomycin (B). Hsp70overexpressing utricles had less hair cell loss after neomycin exposure (D) than wild-type utricles (B). Hair cell counts (E) showed that neomycin causes significant hair cell loss in both the striolar and extrastriolar regions of wild-type mice. Hair cell counts (E) also indicate that the protective effect of Hsp70 overexpression is statistically significant in both the striolar and extrastriolar regions. Asterisks $\left({ }^{*}\right)$ indicate a significant difference in hair cell density. Bars represent mean \pm SEM for $n=7-14$ utricles per condition. Scale bar represents $20 \mu \mathrm{m}$ and applies to all panels. 
utricles had significantly higher hair cell densities at $2 \mathrm{mM} \quad\left(F_{1,70}=7.97, p<0.01\right), 3 \mathrm{mM} \quad\left(F_{1,70}=4.57, p<\right.$ $0.05)$, and $4 \mathrm{mM}$ neomycin $\left(F_{1,70}=9.53, p<0.01\right.$; Fig. 9). These data indicate that Hsp70 overexpression provides significant protection against hair cell death at moderate to high doses of neomycin.

\section{DISCUSSION}

The induction of Hsps is a highly conserved stress response that can promote cellular survival in response to a variety of stresses. We have previously demonstrated that heat shock, which leads to a robust induction of Hsp70, inhibits neomycin-induced hair cell death (Cunningham and Brandon 2006). Here, we have examined the roles of Hsfl and Hsp70 in mediating the protective effect of heat shock. Our data indicate that Hsfl and Hsp70 are both necessary for the protective effect of heat shock against aminoglycoside-induced hair cell death. In addition, we have shown that Hsp70 overexpression provides significant protection against aminoglycoside-induced hair cell death. In addition, Hsp70 overexpression can account for much of the protective effect of heat shock.

In sectioned utricles of CBA mice, we show that heat shock induces Hsp70 in both hair cells and support cells. Western blot analysis of Hsps revealed that heat shock leads to a robust upregulation of

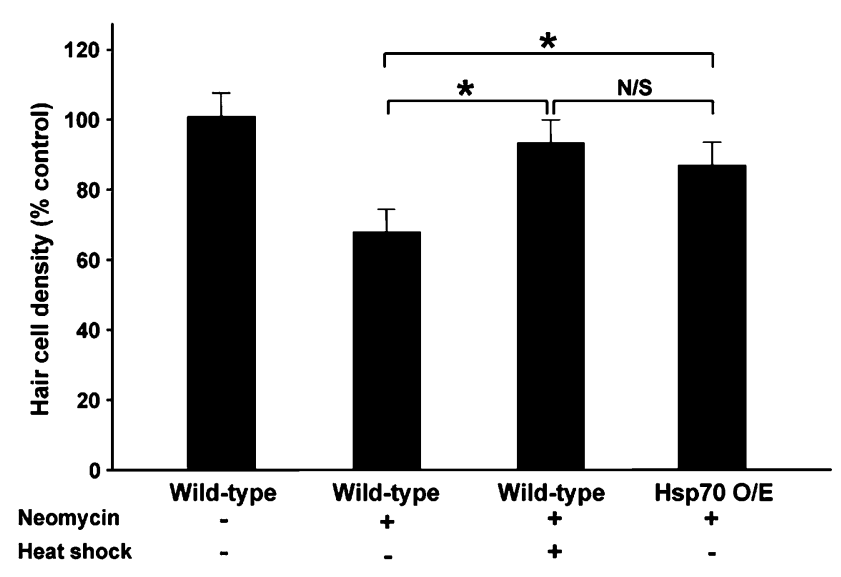

FIG. 8. Hsp70 overexpression can account for much of the protective effect of heat shock. Utricles from wild-type mice were treated either with or without heat shock prior to neomycin exposure. Utricles from Hsp70-overexpressing mice were not heat shocked prior to neomycin exposure. Utricles were fixed and prepared for fluorescent immunohistochemsitry to allow for hair cell counts. Hsp70-overexpressing utricles and heat shocked utricles were significantly protected from neomycin-induced hair cell death. There was no significant difference between hair cell densities of Hsp70-overexpressing utricles and heat-shocked wild-type utricles, both cultured in the presence of neomycin. Asterisks $\left(^{*}\right)$ indicate a significant difference in hair cell densities. N/S Not significant. Bars represent mean \pm SEM for $n=6-12$ utricles per condition.

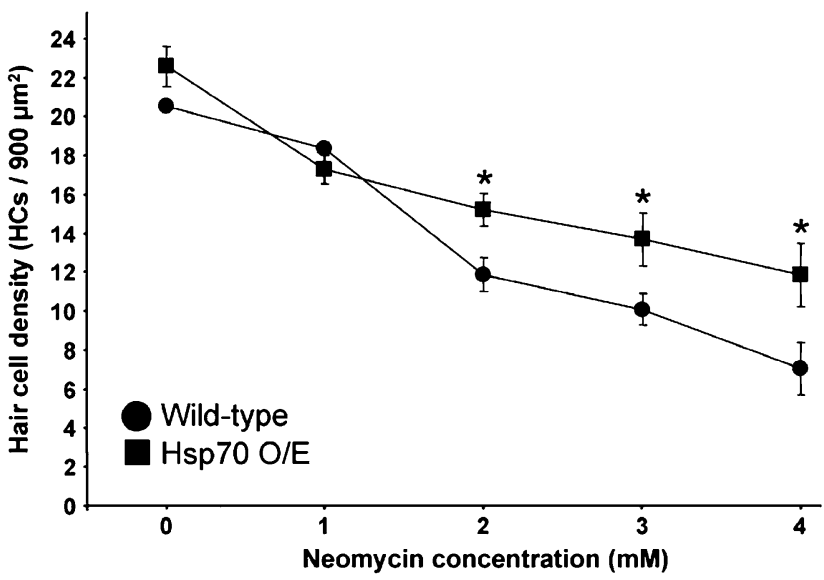

FIG. 9. Hsp70 overexpression inhibits hair cell death at moderate to high doses of neomycin. Utricles from $\mathrm{Hsp} 70$-overexpressing mice and their wild-type littermates were cultured at varying neomycin concentrations for $24 \mathrm{~h}$. Compared to wild-type utricles, Hsp70overexpressing utricles had significantly higher hair cell densities at 2, 3 , and $4 \mathrm{mM}$ neomycin. These data indicate that Hsp70 overexpression significantly inhibits hair cell death at moderate to high doses of neomycin. Asterisks $(*)$ indicate a significant difference in hair cell density in the extrastriolar region of Hsp70-overexpressing utricles versus wild-type utricles. Data points represent mean \pm SEM for $n=3-15$ utricles per condition.

Hsp70 in CBA mice and in wild-type littermates of Hsp70-overexpressing mice. We show that heat shockinduced expression of Hsp70 is much more robust than the Hsp70 expression level achieved by constitutive overexpression of Hsp70 under the control of the human cytomegalovirus immediate early enhancer (hCMV-IE) and chicken $\beta$-actin promoter (Marber et al. 1995). In addition, Hsp27 is slightly upregulated in response to heat shock. Consistent with results at the mRNA level, there is slightly more Hsp27 in utricles of Hsp70-overexpressing mice than in those of their wildtype littermates. While there is no significant difference in Hsp90 mRNA levels, Hsp90 protein levels are decreased in Hsp70-overexpressing utricles compared to wild-type utricles. While Hsp70 has been shown to bind to the transactivation domain of Hsfl to repress its transcriptional activity (Shi et al. 1998), this cannot explain the decreased Hsp90 protein levels, as we saw no difference in Hsp90 mRNA levels between Hsp70overexpressing and wild-type utricles. These data suggest that Hsp90 regulation may undergo Hsp70dependent posttranscriptional regulation. In addition, Hsp27 mRNA and protein levels are increased in Hsp70-overexpressing utricles compared to wild-type utricles, indicating that Hsp27 and Hsp90 expression are differentially regulated.

We previously published a dose-response curve for neomycin in the adult mouse utricle preparation in vitro (Cunningham et al. 2002). In addition, we showed that heat shock inhibits neomycin-induced hair cell death at a single dose of neomycin $(1 \mathrm{mM}$; 
Cunningham and Brandon 2006). However, for a therapy to be potentially clinically useful, it must be protective against hair cell death across a range of neomycin doses. Therefore, we investigated whether heat shock is protective at higher neomycin concentrations. Our data indicate that heat shock provides significant protection against neomycin-induced hair cell death at both moderate and high doses of neomycin. This is in contrast to the protective effect of JNK inhibition on hair cell death which is only observed at moderate doses of neomycin (Sugahara et al. 2006). Thus, heat shock results in a robust protective effect against aminoglycoside-induced hair cell death.

$H s f 1^{-/-}$mice were utilized to examine the role of Hsfl in mediating the protective effect of heat shock against aminoglycoside-induced hair cell death. Hsf1 is the major transcription factor regulating the activation of inducible heat shock proteins. Stressinduced activation of Hsfl involves trimerization, acquisition of DNA-binding activity, and translocation to the nucleus (Baler et al. 1993; Sarge et al. 1993). In the nucleus, Hsf1 binds to heat shock element (HSE) sequences present in the promoter regions of Hsps (Amin et al. 1988). In addition, regulation of Hsf1mediated transcriptional activity is mediated by both constitutive and stress-inducible phosphorylation (Kline and Morimoto 1997; Holmberg et al. 2001, 2002; Guettouche et al. 2005). Hsf1 ${ }^{-/-}$mice are viable but exhibit some degree of prenatal lethality and postnatal growth retardation (Xiao et al. 1999). In addition, Hsfl is required for normal development of the placenta, and female $H s f 1^{-/-}$mice are infertile (Xiao et al. 1999; Christians et al. 2000). Hsf1 ${ }^{-/-}$mice are more susceptible to lipopolysaccharide-induced mortality, cadmium-induced pulmonary damage, and hydrochloric acid- or ethanol-induced gastric lesions (Xiao et al. 1999; Wirth et al. 2004; Tanaka et al. 2007). In the auditory system, $\mathrm{Hsf}^{-1-}$ mice demonstrate increased susceptibility to noise trauma (Sugahara et al. 2003; Fairfield et al. 2005). Our data indicate that the protective effect of heat shock on aminoglycoside-induced vestibular hair cell death requires Hsf1.

We have shown by Western blot analysis that heat shock robustly induces Hsp70. To determine whether the protective effect of heat shock against aminoglycoside-induced hair cell death requires Hsp70, we

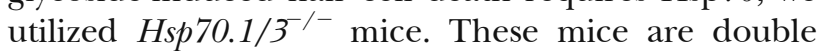
knockouts of Hsp70.1 and Hsp70.3. The locus of the Hsp70.2 gene is intact, however, Hsp70.2 is only expressed in spermatogenic cells (Zakeri et al. 1988). Hunt et al. (2004) demonstrated increased mutations in these mice in response to irradiation, suggesting that Hsp70 plays an important role in the maintenance of genomic stability. In addition,
Hsp $70.1 / 3^{-1}$ mice demonstrate increased susceptibility to ischemia-induced damage to the heart and to acetaminophen-induced hepatotoxicity (Kim et al. 2006; Tolson et al. 2006). We examined the response to heat shock in $H s p 70.1 / 3^{--}$mouse utricles and found that Hsp70 is necessary for the protective effect provided by heat shock against aminoglycosideinduced hair cell death.

Heat stress has been shown to be protective against a number of insults in various systems. For example, short-term total body heat-stress has been shown to prevent light-induced damage to the photoreceptors in the retina, ischemia-induced death of hippocampal neurons and cardiac myocytes, carbon tetrachlorideinduced hepatotoxicity, and lipopolysaccharideinduced pulmonary fibrosis (Barbe et al. 1988; Chopp et al. 1989; Marber et al. 1993; Lee et al. 2004; Hagiwara et al. 2007). In the auditory system, total body heat stress is protective against noise-induced hearing loss (Yoshida et al. 1999). Heat shock results in robust protection against aminoglycoside-induced hair cell death in the mouse utricle preparation. Given that Hsp70 is the most robustly induced Hsp in our system, we examined whether Hsp70 overexpression is sufficient to protect hair cells against aminoglycoside-induced cell death. To address this question, we utilized transgenic mice that constitutively overexpress Hsp70 under the control of the human cytomegalovirus immediate early enhancer (hCMVIE) and chicken $\beta$-actin promoter (Marber et al. 1995). These mice have been shown to be resistant to ischemia in both the heart and brain (Marber et al. 1995; Tsuchiya et al. 2003). Furthermore, Hsp70overexpressing mice are protected against both damage-induced and age-related dysfunction of skeletal muscles (McArdle et al. 2004). Here, we have shown that Hsp70 overexpression results in inhibition of aminoglycoside-induced hair cell death caused by moderate-to-high doses of neomycin. In addition, as the level of protection provided by heat shock in wildtype utricles is similar to the protective effect of Hsp70 overexpression against a moderate dose of neomycin, it appears that Hsp70 overexpression is sufficient to account for much of the protective effect of heat shock at that same dose. Interestingly, Hsp70 protein levels are significantly lower in Hsp70-overexpressing utricles than in heat shocked wild-type utricles, indicating that mild upregulation of Hsp70 is sufficient to inhibit hair cell death induced by aminoglycosides.

Following in vivo administration, aminoglycoside concentrations in the endolymphatic and perilymphatic fluids are lower than in explant culture models (Harpur and Gonda 1982; Forge and Li 2000; Cunningham et al. 2002, 2004; Ding et al. 2003; Takumida and Anniko 2005; Cunningham and Brandon 2006; Sugahara et al. 
2006; Taura et al. 2006). The aminoglycoside concentrations required to induce hair cell death in the adult mouse utricle preparation are consistently in the millimolar range (Cunningham et al. 2002, 2004; Cunningham and Brandon 2006; Sugahara et al. 2006). This concentration range is similar to what has been used by other investigators for examining hair cell death in vestibular explant cultures from adult mammals (Forge and Li 2000; Park et al. 2007) and postnatal mammalian vestibular explants (Quint et al. 1998; Berggren et al. 2003) and organotypic cultures of postnatal mammalian cochlea (Ding et al. 2002; Wei et al. 2005). There are several possible reasons that higher concentrations are required in in vitro systems. First, aminoglycosides have been suggested to enter hair cells through the mechanotransduction channel (Gale et al. 2001; Marcotti et al. 2005), which is likely less active in explant cultures. Secondly, it is conceivable that the process of explanting the utricles may result in significant damage to tip links, again limiting aminoglycoside entry via transduction channels. Thirdly, it is difficult to mimic the clinical scenario of chronic exposure to low doses of aminoglycosides in vitro because explant cultures cannot be maintained in culture for the extended periods of time required to induce damage by chronic aminoglycoside exposure. To overcome this limitation of the in vitro model system, explant cultures are exposed acutely to higher doses of aminoglycosides to induce damage. Studies involving in vitro model systems must therefore be followed up by in vivo experiments to determine whether the in vitro model system recapitulates the in vivo situation.

The use of Hsp70 as a clinical therapy would require a method of inducing Hsp70, either via heat shock, or via pharmaceutical induction of Hsp70. Sugahara et al. (2003) have shown that local hyperthermia can induce Hsp70 in the guinea pig cochlea similarly to whole-body heat stress (Dechesne et al. 1992). Both local and whole-body hyperthermia inhibit hearing loss and noise-induced loss of sensory cells in the inner ear (Yoshida et al. 1999; Sugahara et al. 2003). Geranylgeranylacetone (GGA) is an example of an available therapeutic drug that has been shown to induce Hsps in several systems. GGA is an isoprenoid that is used clinically for the treatment of gastritis and gastric ulcers (Murakami et al. 1981, 1982a, b). GGA induces Hsp70 in a variety of tissues, including the gastric mucosa, heart, liver, brain, and cochlea (Hirakawa et al. 1996; Ooie et al. 2001; Oda et al. 2002; Mikuriya et al. 2005; Sone et al. 2005). In designing a therapy aimed at the prevention of druginduced hearing loss and/or balance disorders, Hsp70 induction by GGA or other pharmaceutical inducers may represent a rational alternative to induction by local and whole-body heat stress. Interestingly, two recent studies have demonstrated the protective effect of GGA against aminoglycosideinduced vestibular and cochlear damage in vitro (Takumida and Anniko 2005; Sano et al. 2007). Altogether, these data suggest that pharmaceutical induction of Hsps may represent a candidate cotherapy aimed at the inhibition of ototoxic druginduced hair cell apoptosis.

Here, we present three lines of evidence indicating that $\mathrm{Hsp70}$ is the major mediator underlying the protective effect of heat shock against aminoglycosideinduced hair cell death. First, utricles from Hsp70.1/ $3^{-/-}$mice lose all of the protective effect of heat shock against aminoglycoside-induced cell death, while this protective effect is observed in wild-type utricles. Second, the neomycin dose-response curve is similar in Hsp70-overexpressing utricles and in heat shocked utricles of CBA mice. Third, Hsp70 overexpression accounts for much of the protective effect of heat shock in wild-type utricles against hair cell death induced by a moderate dose of neomycin. These data indicate that Hsp70 is both necessary for the protective effect of heat shock and that overexpression of Hsp70 provides significant protection against aminoglycoside-induced hair cell death. Taken together, Hsp70 induction may represent a potential clinical therapy against aminoglycoside-induced hearing and balance disorders. Studies are currently underway directed at elucidating the mechanism(s) by which Hsp70 protects hair cells from aminoglycoside-induced death.

\section{ACKNOWLEDGMENTS}

The authors gratefully acknowledge Dr. Anna Lysakowski's guidance in the preparation of utricular sections. This work was supported by NIH DC07613 and by NIH/NCRR extramural research facilities (C06) grants C06 RR015455 and C06 RR14516 from the Extramural Research Facilities Program of the National Center for Research Resources.

\section{REFERENCES}

Adams PF, Hendershot GE, Marano MA. Current estimates from the National Health Interview Survey, 1996. In: Vital and health statistics. Series 10, Data from the National Health Survey. Centers for Disease Control and Prevention/National Center for Health Statistics, 1999.

Amin J, Ananthan J, Voellmy R. Key features of heat shock regulatory elements. Mol. Cell. Biol. 8:3761-3769, 1988.

Anckar J, Sistonen L. Heat shock factor 1 as a coordinator of stress and developmental pathways. Adv. Exp. Med. Biol. 594:78-88, 2007.

Baler R, Dahl G, Voellmy R. Activation of human heat shock genes is accompanied by oligomerization, modification, and rapid translocation of heat shock transcription factor HSF1. Mol. Cell. Biol. 13:2486-2496, 1993. 
Barbe MF, Tytell M, Gower DJ, Welch WJ. Hyperthermia protects against light damage in the rat retina. Science 241:1817-1820, 1988.

Beere HM, Wolf BB, Cain K, Mosser DD, Mahboubi A, Kuwana T, Tailor P, Morimoto RI, Cohen GM, Green DR. Heat-shock protein 70 inhibits apoptosis by preventing recruitment of procaspase-9 to the Apaf-1 apoptosome. Nat. Cell Biol. 2:469$475,2000$.

Berggren D, Liu W, Frenz D, Van De Water T. Spontaneous hair-cell renewal following gentamicin exposure in postnatal rat utricular explants. Hear. Res. 180:114-125, 2003.

Cheng AG, Cunningham LL, Rubel EW. Hair cell death in the avian basilar papilla: characterization of the in vitro model and caspase activation. J. Assoc. Res. Otolaryngol. 4:91-105, 2003.

Chopp M, Chen H, Ho KL, Dereski MO, Brown E, Hetzel FW, Welch KM. Transient hyperthermia protects against subsequent forebrain ischemic cell damage in the rat. Neurology 39:1396-1398, 1989.

Christians E, Davis AA, Thomas SD, Benjamin IJ. Maternal effect of Hsfl on reproductive success. Nature 407:693-694, 2000.

CunNingham LL. The adult mouse utricle as an in vitro preparation for studies of ototoxic drug-induced sensory hair cell death. Brain Res. 1091(1):277-281, 2006.

Cunningham LL, Brandon CS. Heat shock inhibits both aminoglycoside- and cisplatin-induced sensory hair cell death. J. Assoc. Res. Otolaryngol. 7:299-307, 2006.

Cunningham LL, Cheng AG, Rubel EW. Caspase activation in hair cells of the mouse utricle exposed to neomycin. J. Neurosci. 22:8532-8540, 2002.

Cunningham LL, Matsui Ji, Warchol ME, Rubel EW. Overexpression of Bcl-2 prevents neomycin-induced hair cell death and caspase9 activation in the adult mouse utricle in vitro. J. Neurobiol. 60:89-100, 2004.

Dechesne CJ, Kim HN, Nowak TS, JR, Wenthold RJ. Expression of heat shock protein, HSP72, in the guinea pig and rat cochlea after hyperthermia: immunochemical and in situ hybridization analysis. Hear. Res. 59:195-204, 1992.

Desai SS, Zeh C, Lysakowski A. Comparative morphology of rodent vestibular periphery. I. Saccular and utricular maculae. J. Neurophysiol. 93:251-266, 2005.

Ding D, Stracher A, Salvi RJ. Leupeptin protects cochlear and vestibular hair cells from gentamicin ototoxicity. Hear. Res. 164:115-126, 2002.

Ding D, McFadden SL, Browne RW, Salvi RJ. Late dosing with ethacrynic acid can reduce gentamicin concentration in perilymph and protect cochlear hair cells. Hear. Res. 185:90-96, 2003.

Eshraghi AA, Wang J, Adil E, He J, Zine A, Bublik M, Bonny C, Puel JL, Balkany TJ, VAN De Water TR. Blocking c-Jun-N-terminal kinase signaling can prevent hearing loss induced by both electrode insertion trauma and neomycin ototoxicity. Hear. Res. 226:168-177, 2007.

Fairfield DA, Lomax Mi, Dootz GA, Chen S, Galecki AT, Benjamin IJ, Dolan DF, Altschuler RA. Heat shock factor 1-deficient mice exhibit decreased recovery of hearing following noise overstimulation. J. Neurosci. Res. 81:589-596, 2005.

Forge A, LI L. Apoptotic death of hair cells in mammalian vestibular sensory epithelia. Hear. Res. 139:97-115, 2000.

Gale Je, Marcotti W, Kennedy HJ, Kros CJ, Richardson GP. FM1-43 dye behaves as a permeant blocker of the hair-cell mechanotransducer channel. J. Neurosci. 21:7013-7025, 2001.

Guettouche T, Boellmann F, Lane WS, Voellmy R. Analysis of phosphorylation of human heat shock factor 1 in cells experiencing a stress. BMC Biochem. 6:4, 2005.

Hagiwara S, Iwasaka H, Matsumoto S, Noguchi T, Yoshioka $\mathrm{H}$. Association between heat stress protein 70 induction and decreased pulmonary fibrosis in an animal model of acute lung injury. Lung 185:287-293, 2007.
HaRpur ES, Gonda I. Analysis of the phamacokinetics of ribostamycin in serum and perilymph of guinea pigs after single and multiple doses. Br. J. Audiol. 16:95-99, 1982.

HARTL FU. Molecular chaperones in cellular protein folding. Nature 381:571-579, 1996.

Hirakawa T, Rokutan K, NikaWa T, Kishi K. Geranylgeranylacetone induces heat shock proteins in cultured guinea pig gastric mucosal cells and rat gastric mucosa. Gastroenterology 111:345357, 1996

Holmberg Ci, Hietakangas V, Mikhailov A, Rantanen JO, Kallio M, Meinander A, Hellman J, Morrice N, MacKintosh C, Morimoto RI, Eriksson JE, Sistonen L. Phosphorylation of serine 230 promotes inducible transcriptional activity of heat shock factor 1. EMBO J. 20:3800-3810, 2001.

Holmberg CI, Tran SE, Eriksson Je, Sistonen L. Multisite phosphorylation provides sophisticated regulation of transcription factors. Trends Biochem. Sci. 27:619-627, 2002.

Hunt CR, Dix DJ, Sharma GG, Pandita RK, Gupta A, Funk M, Pandita TK. Genomic instability and enhanced radiosensitivity in Hsp70.1- and Hsp70.3-deficient mice. Mol. Cell. Biol. 24:899911, 2004.

Jaattela M, Wissing D, Kokholm K, Kallunki T, Egeblad M. Hsp70 exerts its anti-apoptotic function downstream of caspase-3-like proteases. EMBO J. 17:6124-6134, 1998.

Kim YK, Suarez J, Hu Y, McDonough PM, Boer C, Dix DJ, Dillmann WH. Deletion of the inducible 70-kDa heat shock protein genes in mice impairs cardiac contractile function and calcium handling associated with hypertrophy. Circulation 113:25892597, 2006.

KLINe MP, Morimoto RI. Repression of the heat shock factor 1 transcriptional activation domain is modulated by constitutive phosphorylation. Mol. Cell. Biol. 17:2107-2115, 1997.

Lang H, LiU C. Apoptosis and hair cell degeneration in the vestibular sensory epithelia of the guinea pig following a gentamicin insult. Hear. Res. 111:177-184, 1997.

Lee KJ, Terada K, Oyadomari S, Inomata Y, Mori M, Gotoh T. Induction of molecular chaperones in carbon tetrachloridetreated rat liver: implications in protection against liver damage. Cell Stress Chaperones 9:58-68, 2004.

Li CY, LeE JS, Ko YG, Kim JI, Seo JS. Heat shock protein 70 inhibits apoptosis downstream of cytochrome c release and upstream of caspase-3 activation. J. Biol. Chem. 275:25665-25671, 2000.

Mangiardi DA, Mclaughlin-Williamson K, May KE, Messana EP, Mountain DC, Cotanche DA. Progression of hair cell ejection and molecular markers of apoptosis in the avian cochlea following gentamicin treatment. J. Comp. Neurol. 475:1-18, 2004.

Marber MS, Latchman DS, Walker JM, Yellon DM. Cardiac stress protein elevation 24 hours after brief ischemia or heat stress is associated with resistance to myocardial infarction. Circulation 88:1264-1272, 1993.

Marber MS, Mestril R, Chi SH, Sayen Mr, Yellon DM, Dillmann WH. Overexpression of the rat inducible $70-\mathrm{kD}$ heat stress protein in a transgenic mouse increases the resistance of the heart to ischemic injury. J. Clin. Invest. 95:1446-1456, 1995.

Marcotti W, van Netten SM, Kros CJ. The aminoglycoside antibiotic dihydrostreptomycin rapidly enters mouse outer hair cells through the mechano-electrical transducer channels. J. Physiol. 567:505-521, 2005.

Martindale JL, Holbrook NJ. Cellular response to oxidative stress: signaling for suicide and survival. J. Cell. Physiol. 192:1-15, 2002.

Matsui JI, Ogilvie JM, Warchol ME. Inhibition of caspases prevents ototoxic and ongoing hair cell death. J. Neurosci. 22:1218-1227, 2002.

Matsui Ji, Haque A, Huss D, Messana EP, Alosi JA, Roberson DW, Cotanche DA, Dickman JD, Warchol ME. Caspase inhibitors promote vestibular hair cell survival and function after aminoglycoside treatment in vivo. J. Neurosci. 23:6111-6122, 2003. 
Matsui JI, Gale JE, Warchol ME. Critical signaling events during the aminoglycoside-induced death of sensory hair cells in vitro. J. Neurobiol. 61:250-266, 2004.

McArdle A, Dillmann WH, Mestril R, Faulkner JA, Jackson MJ. Overexpression of HSP70 in mouse skeletal muscle protects against muscle damage and age-related muscle dysfunction. FASEB J. 18:355-357, 2004.

McMillan DR, Xiao X, Shao L, Graves K, Benjamin IJ. Targeted disruption of heat shock transcription factor 1 abolishes thermotolerance and protection against heat-inducible apoptosis. J. Biol. Chem. 273:7523-7528, 1998.

Mikuriya T, Sugahara K, Takemoto T, Tanaka K, Takeno K, Shimogori H, NaKa A, Yamashita H. Geranylgeranylacetone, a heat shock protein inducer, prevents acoustic injury in the guinea pig. Brain Res. 1065:107-114, 2005.

Mosser DD, Caron AW, Bourget L, Denis-Larose C, Massie B. Role of the human heat shock protein hsp70 in protection against stressinduced apoptosis. Mol. Cell. Biol. 17:5317-5327, 1997.

Murakami M, Oketani K, Fujisaki H, Wakabayashi T, Ohgo T. Antiulcer effect of geranylgeranylacetone, a new acyclic polyisoprenoid on experimentally induced gastric and duodenal ulcers in rats. Arzneimittelforschung 31:799-804, 1981.

Murakami M, Oketani K, Fujisaki H, Wakabayashi T. Effect of geranylgeranylacetone (GGA) on gastric lesions induced by topical aspirin plus HCl. Jpn. J. Pharmacol. 32:921-924, 1982a.

Murakami M, Oketani K, Fujisaki H, Wakabayashi T, Ohgo T, Okabe S. Effects of the antiulcer drug geranylgeranylacetone on aspirininduced gastric ulcers in rats. Jpn. J. Pharmacol. 32:299-306, 1982b.

Oda H, Miyake H, Imata T, Kusumoto K, Rokutan K, Tashiro S. Geranylgeranylacetone suppresses inflammatory responses and improves survival after massive hepatectomy in rats. J. Gastrointest. Surg. 6:464-472, 2002, discussion 473.

Ooie T, Takahashi N, Saikawa T, Nawata T, Arikawa M, Yamanaka K, Hara M, Shimada T, Sakata T. Single oral dose of geranylgeranylacetone induces heat-shock protein 72 and renders protection against ischemia/reperfusion injury in rat heart. Circulation 104:1837-1843, 2001.

Pandey P, Saleh A, Nakazawa A, Kumar S, Srinivasula SM, Kumar V, Weichselbaum R, Nalin C, Alnemri ES, Kufe D, Kharbanda S. Negative regulation of cytochrome $c$-mediated oligomerization of Apaf-1 and activation of procaspase-9 by heat shock protein 90. EMBO J. 19:4310-4322, 2000.

PARK JY, PARK YH, ShIN DH, OH SH. Insulin-like growth factor binding protein (IGFBP)-mediated hair cell survival on the mouse utricle exposed to neomycin: the roles of IGFBP-4 and IGFBP-5. Acta Otolaryngol Suppl. 127(1)22-29, 2007.

Pirvola U, Xing-Qun L, Virkkala J, Saarma M, Murakata C, Camoratto AM, WALton KM, YLikoski J. Rescue of hearing, auditory hair cells, and neurons by CEP-1347/KT7515, an inhibitor of c-Jun Nterminal kinase activation. J. Neurosci. 20:43-50, 2000.

Quint E, Furness DN, HackNeY CM. The effect of explantation and neomycin on hair cells and supporting cells in organotypic cultures of the adult guinea-pig utricle. Hear. Res. 118:157-167, 1998.

Saleh A, Srinivasula SM, Balkir L, Robbins PD, Alnemri ES. Negative regulation of the Apaf-1 apoptosome by Hsp70. Nat. Cell Biol. 2:476-483, 2000.

Sano H, Yoneda S, Iwase H, Itoh A, Hashimoto D, Окamoto M. Effect of geranylgeranylacetone on gentamycin ototoxicity in rat cochlea culture. Auris Nasus Larynx 34:1-4, 2007.

SARge KD, Murphy SP, Morimoto RI. Activation of heat shock gene transcription by heat shock factor 1 involves oligomerization, acquisition of DNA-binding activity, and nuclear localization and can occur in the absence of stress. Mol. Cell. Biol. 13:1392-1407, 1993.

SHi Y, Mosser DD, Morimoto RI. Molecular chaperones as HSF1specific transcriptional repressors. Genes Dev. 12:654-666, 1998.

Sone M, Hayashi H, Yamamoto H, Hoshino T, Mizushima T, Nakashima T. Upregulation of HSP by geranylgeranylacetone protects the cochlear lateral wall from endotoxin-induced inflammation. Hear. Res. 204:140-146, 2005.

Sugahara K, Inouye S, izu H, Katoh Y, Katsuki K, Takemoto T, Shimogori H, Yamashita H, Nakai A. Heat shock transcription factor HSF1 is required for survival of sensory hair cells against acoustic overexposure. Hear. Res. 182:88-96, 2003.

Sugahara K, Rubel EW, Cunningham LL. JNK signaling in neomycininduced vestibular hair cell death. Hear. Res. 221:128-135, 2006.

Tabuchi K, Pak K, Chavez E, Ryan AF. Role of inhibitor of apoptosis protein in gentamicin-induced cochlear hair cell damage. Neuroscience 149:213-222, 2007.

TAKUmida M, ANNiKo M. Heat shock protein 70 delays gentamicininduced vestibular hair cell death. Acta Otolaryngol. 125:23-28, 2005.

Tanaka K, Tsutsumi S, Arai Y, Hoshino T, Suzuki K, Takaki E, Ito T, Takeuchi K, Nakai A, Mizushima T. Genetic evidence for a protective role of heat shock factor 1 against irritant-induced gastric lesions. Mol. Pharmacol. 71:985-993, 2007.

Taura A, Kojima K, Ito J, Ohmori H. Recovery of hair cell function after damage induced by gentamicin in organ culture of rat vestibular maculae. Brain Res. 1098:33-48, 2006.

Tolson JK, Dix DJ, Voellmy RW, RoberTs SM. Increased hepatotoxicity of acetaminophen in Hsp70i knockout mice. Toxicol. Appl. Pharmacol. 210:157-162, 2006.

Tsuchiya D, Hong S, Matsumori Y, Shinna H, Kayama T, Swanson RA, Dillman WH, Liu J, Panter SS, Weinstein PR. Overexpression of rat heat shock protein 70 is associated with reduction of early mitochondrial cytochrome $\mathrm{C}$ release and subsequent DNA fragmentation after permanent focal ischemia. J. Cereb. Blood Flow Metab. 23:718-727, 2003

Wei X, Zhao L, Liu J, Dodel RC, Farlow MR, Du Y. Minocycline prevents gentamicin-induced ototoxicity by inhibiting p38 MAP kinase phosphorylation and caspase 3 activation. Neuroscience 131:513-521, 2005.

Wirth D, Bureau F, Melotte D, Christians E, Gustin P. Evidence for a role of heat shock factor 1 in inhibition of NF-kappaB pathway during heat shock response-mediated lung protection. Am. J. Physiol. Lung Cell. Mol. Physiol. 287:L953-961, 2004.

Wright GD, Thompson PR. Aminoglycoside phosphotransferases: proteins, structure, and mechanism. Front Biosci. 4:D9-D21, 1999.

Xiao X, Zuo X, Davis AA, McMillan DR, Curry BB, Richardson JA, BENJAMIN IJ. HSF1 is required for extra-embryonic development, postnatal growth and protection during inflammatory responses in mice. EMBO J. 18:5943-5952, 1999.

Ylikoski J, Xing-Qun L, Virkkala J, Pirvola U. Blockade of c-Jun Nterminal kinase pathway attenuates gentamicin-induced cochlear and vestibular hair cell death. Hear. Res. 166:33-43, 2002.

Yoshida N, Kristiansen A, Liberman MC. Heat stress and protection from permanent acoustic injury in mice. J. Neurosci. 19:1011610124, 1999.

Zakeri ZF, Wolgemuth DJ, Hunt CR. Identification and sequence analysis of a new member of the mouse HSP70 gene family and characterization of its unique cellular and developmental pattern of expression in the male germ line. Mol. Cell. Biol. 8:2925-2932, 1988. 